\title{
Clinical Profile and Predictors of Severe Malaria: A Study from Two Tertiary Care Centers in İstanbul
}

\section{Şiddetli Sıtmanın Klinik Profili ve Göstergeleri: İstanbul'da İki Üçüncü Basamak Hastaneden Çalışma}

\author{
Ramazan Korkusuz ${ }^{1}$, (1) Şemsi Nur Karabela1, (1) Nagehan Didem Sarı², (1) Sevtap Şenoğlu¹, \\ (D) Esra Canbolat Ünlü11, (D) Kadriye Kart Yaşar ${ }^{1}$ \\ ${ }^{1}$ University of Health Sciences Turkey, Bakirköy Dr. Sadi Konuk Training and Research Hospital, Clinic of Infectious Diseases and Clinical \\ Microbiology, İstanbul, Turkey \\ 2University of Health Sciences Turkey, İstanbul Training and Research Hospital, Clinic of Infectious Diseases and Clinical Microbiology, İstanbul, \\ Turkey
}

\begin{abstract}
Objective: This study aimed to determine discriminating findings of severe malaria cases compared with other cases.

Methods: Epidemiological, laboratory, and clinical features of the patients were collected retrospectively from two tertiary centers. The diagnosis was established in all cases by the detection of trophozoite and/or gametocyte forms of the parasite in the microscopic examination. "Severe malaria" with a serious clinical course was defined according to 2015 World Health Organization data.

Results: This study included 94 patients with imported malaria composed of 85 male (90.4\%) and 9 female (9.6\%) patients with a mean age of $32.4 \pm 4.56$ years. P. falciparum $(n=72,76.6 \%)$ and $P$. vivax $(n=15,15.9 \%)$ were the most frequently identified agents. Of all cases, $12.7 \%$ ( $n=12)$ were defined as severe malaria. The frequency of abdominal pain, diarrhea, splenomegaly, and deep thrombocytopenia were significantly higher in severe malaria cases than in other cases $(p=0.002 ; p=0.001 ; p=0.046 ; p=0.041$, respectively).

Conclusion: The frequencies of abdominal pain, diarrhea, splenomegaly, and deep thrombocytopenia were significantly higher in severe malaria cases than in other cases. These factors can be accepted as predictors of severe malaria.
\end{abstract}

Keywords: Malaria, Plasmodium, Plasmodium falciparum, severe malaria

\section{öz}

Amaç: Bu çalışma, klinik seyri ciddi olan sıtma olgularının diğer olgulara göre ayırııı bulgularına dikkat çekmeyi amaçlamıştır.

Gereç ve Yöntem: Hastaların epidemiyolojik, laboratuvar ve klinik özellikleri retrospektif olarak toplandı. Tüm olgularda mikroskobik incelemede parazitin trofozoit ve/veya gametosit formlarının saptanmasıyla tanı konuldu. Dünya Sağlık Örgütü 2015 verilerine göre ciddi klinik seyir gösteren "şiddetli sıtma olguları" tanımlanmıştır.

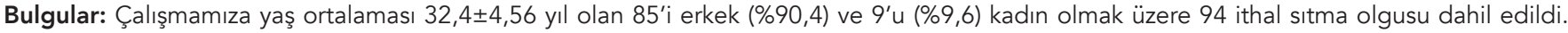
P. falciparum $72(\% 76,6)$ ve P. vivax $15(\% 15,9)$ en sık saptanan etkenlerdi. Tüm olguların; \%12,7'si $(12$ olgu) "şiddetli sıtma olgusu" olarak tanımlandı. Klinik seyri ağır olan "şiddetli sıtma" olgularında karın ağrısı, ishal, splenomegali ve derin trombositopeni sıklığı diğer olgulara göre istatistiksel olarak anlamlı derecede yüksek bulundu ( $p=0,002 ; p=0,001 ; p=0,046 ; p=0,041$, sırasıly).

Sonuç: Çalışmamızın sonuçlarına göre karın ağrısı, ishal, splenomegali ve derin trombositopeni sıklıkları diğer olgulara göre anlamlı derecede yüksek bulundu ve bu faktörler şiddetli sıtmanın göstergesi olarak kabul edilebilir.

Anahtar Kelimeler: Sıtma, Plasmodium, Plasmodium falciparum, şiddetli sıtma

Address for Correspondence: Ramazan Korkusuz, University of Health Sciences Turkey, Bakirköy Dr. Sadi Konuk Training and Research Hospital, Clinic of Infectious Diseases and Clinical Microbiology, İstanbul, Turkey

E-mail: ramazankorkusuz@hotmail.com ORCID ID: orcid.org/0000-0002-9988-9596

Cite as: Korkusuz R, Karabela ŞN, Sarı ND, Şenoğlu S, Canbolat Ünlü E, Kart Yaşar K, Clinical Profile and Predictors of Severe Malaria: A Study from Two Tertiary Care Centers in Istanbul. Med J Bakirkoy 2021;17:268-273 


\section{INTRODUCTION}

Malaria is a major pandemic disease caused by parasitic protozoa of the genus Plasmodium. The disease name "malaria" means "bad air" as it occurs by inhalation of bad air from marshlands. It is a parasitic disease transmitted through the bite of female Anopheles mosquito that usually appears between dusk and dawn. The rare mechanisms of transmission include congenitally acquired disease, blood transfusion, shared use of contaminated needles, organ transplantation, and nosocomial transition (1-3). Of the five Plasmodium species that infect humans, P. falciparum and P. vivax are responsible for most of the cases (4). The World Health Organization (WHO) has reported that approximately 238 million and 229 million malaria cases occurred in 2010 and 2019 worldwide, respectively, and that these cases were most commonly found in Africa (94\%), Southeast Asia, and East Mediterranean regions. Moreover, approximately 409,000 deaths are caused by malaria annually, and $>90 \%$ of those deaths occurred in the sub-Saharan African region (4).

Malaria may present different clinical pictures as well as nonspecific and classical symptoms. Mild symptoms are observed in individuals with asymptomatic parasitemia, while the clinical course may range from moderate to comatose states and ends in patient death with severe anemia, metabolic acidosis, cerebral malaria, and multiorgan involvement. Severe malaria is mostly caused by P. falciparum (90\%); however, P. vivax and P. knowlesi may cause serious disease (4-7).

WHO has defined severe malaria as the occurrence of unconsciousness or comatose, inability to stand without support, having more than two convulsion attacks within $24 \mathrm{~h}$, acidosis, hypoglycemia (blood glucose $<40 \mathrm{mg} / \mathrm{dL}$ ), serious malarial anemia (hemoglobin $<7 \mathrm{~g} / \mathrm{dL}$ ), renal failure, hyperbilirubinemia (total bilirubin $>3 \mathrm{mg} / \mathrm{dL}$ ), pulmonary edema, abnormal spontaneous bleeding, shock, and hyperparasitemia (8).

No new endemic malaria cases originating from the southeast Anatolia region in Turkey were detected since 2010. By contrast, cases observed in the recent 10 years were relapse cases caused by hypnozoites (9). However, imported malaria cases observed after travels to tropical regions, primarily Africa, have threatened the health of our citizens who frequently travel to high-risk regions for business, tourism, humanitarian aid, etc. Thus, this study aimed to examine discriminating findings of severe malaria cases compared with other cases and to determine the clinical profile and predictors of severe malaria by retrospectively analyzing cases followed in two centers.

\section{METHODS}

This study included imported malaria cases followed up between 2011 and 2019 in two infectious diseases and clinical microbiology clinics in Istanbul, Turkey. Epidemiological, clinical, and laboratory data and treatment-related and clinical course features of the patients were collected retrospectively. The study was approved by the University of Health Sciences Turkey, Bakırköy Dr. Sadi Konuk Training and Research Hospital Local Ethics Committee (2019-04-15/201978). Informed consent forms were signed by the patients.

The diagnosis was established in all cases by the detection of trophozoite and/or gametocyte forms of the parasite during the microscopic examination performed after staining of thick-drop and peripheral smear slides by Giemsa stain prepared from peripheral blood samples obtained during the feverish period. The diagnosis of imported malaria was also confirmed by the Department of Malaria Control of Istanbul Province Public Health Directorate. Patients with severe malaria were treated by oral or parenteral administrations of antimalarial medicines (Artemether-lumefantrine, quinine, primaquine, doxycycline, etc.) supplied by the Department of Malaria Control. For monitoring of the parasitemia load, thick-drop and peripheral smear examinations were performed at baseline and daily or 8-h intervals when needed during the hospitalization process until finalization of the parasitemia. "Severe malaria" with a serious clinical course was defined according to 2015 WHO data (8). Clinical and laboratory findings of patients with and without severe malaria were compared.

\section{Statistical Analysis}

Data obtained in the study were analyzed statistically using SPSS version 18.0 software. Descriptive statistics were reported as number ( $n$ ) and percentage (\%) for categorical variables and as mean \pm standard deviation values for continuous variables. In the group comparisons, the chi-square test and Fisher's Exact test were applied to categorical variables. Student's t-test was used for the comparison of two groups of continuous variables. A value of $p<0.05$ was accepted as significant.

\section{RESULTS}

This study included 94 patients with imported malaria, composed of 85 male (90.4\%) and 9 female (9.6\%) patients with a mean age of $32.4 \pm 4.56$ (range, 18 and 62) years. Of the patients, $85 \%$ and $15 \%$ reported trips to African and Southeast Asian regions in their medical history, respectively. Chemoprophylaxis was not received by $94.7 \%$ 
of the patients before their trips. The clinical and laboratory findings of the patients at initial application are summarized in Table 1.

P. falciparum ( $n=72,76.6 \%)$ and P.vivax $(n=15,15.9 \%)$ were the most frequently identified agents in our cases. The most commonly seen symptoms at baseline physical examination were high fever (100\%), chills/shivering (78.7\%), and headache (64\%), whereas the most frequent findings were thrombocytopenia (90.5\%), anemia (73.4\%), and splenomegaly (67\%). Severe thrombocytopenia $(<50.000$ $10^{3} / \mu \mathrm{L}$ ) was present in approximately $40 \%$ of the patients.

Of all the patients, $12.7 \%(n=12)$ were diagnosed with severe malaria with a serious clinical course. Cerebral involvement and jaundice were monitored in 10 (83.3\%) and 5 (41.7\%) of those patients, respectively, whereas no hypoglycemia, acute pulmonary edema, and hemorrhage were recorded among them. Moreover, 4 (33.3\%) patients with severe malaria with a serious clinical course caused by P. falciparum died. Table 2 presents the comparison between severe malaria with a serious clinical course and other cases regarding clinical and laboratory findings.

The frequency of abdominal pain, diarrhea, splenomegaly, and severe thrombocytopenia was significantly higher in patients with severe malaria with a serious clinical course than in other cases $(p=0.002 ; p=0.001 ; p=0.046 ; p=0.041$, respectively).

Artemisinin-based antimalarial treatment and quininebased antimalarial treatment were administered in $86 \%$ and $6 \%$ of the patients, respectively. Since adequate treatment response to standard treatment could not be achieved in $8 \%$ of the patients, a combined or consecutive treatment using artemisinin-derived and quinine-derived antimalarial agents were needed.

\section{DISCUSSION}

Malaria is an infectious disease that may present a fatal progression unless diagnosed and treated early. According to a WHO report, malaria takes the second and fifth places in Africa and the world, respectively, as the cause of deaths from infectious diseases. The malarial load is disproportionally high in Africa, and more than $90 \%$ of malaria cases were reported in Africa in 2019 (4).

Turkey is still under the threat of malaria because of increased travel opportunities, increased migration, and labor force mobility among countries as well as uncontrolled migration

Table 1. Clinical and laboratory findings of the patients at initial presentation

\begin{tabular}{|c|c|c|c|}
\hline Demographic and clinical features & $(n=94, \%)$ & Laboratory findings & $(n=94, \%)$ \\
\hline Male & $85(90.4)$ & P. falciparum & $72(76.6)$ \\
\hline Female & $9(9.6)$ & P. vivax & $15(15.9)$ \\
\hline Age (mean) & $32.4 \pm 4.6$ years & P. falciparum $+P$. vivax & $6(6.4)$ \\
\hline Fever & $94(100)$ & P. falciparum + P. ovale & $1(1.1)$ \\
\hline Chills and shivering & $74(78.7)$ & Leukocyte $\left(<500010^{3} / \mu \mathrm{L}\right)$ & $58(61.7)$ \\
\hline Headache & $60(63.8)$ & Thrombocyte $\left(10^{3} / \mu \mathrm{L}\right)$ & - \\
\hline Sweating & $47(50)$ & $>150,000$ & $9(9.5)$ \\
\hline Fatigue & $39(41.5)$ & $50,000-150,000$ & $48(51)$ \\
\hline Nausea and vomiting & $25(26.6)$ & $<50,000$ & $37(39.3)$ \\
\hline Abdominal pain & $25(26.6)$ & Hemoglobin (<13 g/dL) & $69(73.4)$ \\
\hline Diarrhea & $11(11.7)$ & Hemoglobin (<7 g/dL) & $8(8.5)$ \\
\hline Altered consciousness & $10(10.6)$ & Creatinine (>1 mg/dL) & $19(20.2)$ \\
\hline Splenomegaly & $63(67)$ & Renal failure (>3 mg/dL) & $6(6.4)$ \\
\hline Hepatomegaly & $29(30.8)$ & LFT (AST, ALT) (>40 IU/L) & $48(51)$ \\
\hline Cerebral involvement & $10(10.6)$ & T. bilirubin (>3 mg/dL) & $5(5.3)$ \\
\hline Use of prophylaxis & $5(5.3)$ & - & - \\
\hline ICU admission & $3(3.2)$ & - & - \\
\hline Mortality & $4(4.2)$ & - & - \\
\hline
\end{tabular}

LFT: Liver function test, ICU: Intensive care unit, LFT: Liver function test, AST: Aspartate aminotransferase ALT: Alanine aminotransferase 


\begin{tabular}{|c|c|c|c|}
\hline & $\begin{array}{l}\text { Non-severe } \\
(n=82, \%)\end{array}$ & $\begin{array}{l}\text { Severe } \\
(n=12, \%)\end{array}$ & $p$ \\
\hline Age mean $\pm \mathrm{SD}$ & $\begin{array}{l}31.8 \pm 3.49 \\
\text { years }\end{array}$ & $\begin{array}{l}34.2 \pm 9 \\
\text { years }\end{array}$ & \multirow{2}{*}{${ }^{\mathrm{a}} 0.380$} \\
\hline Min-max (median) & $\begin{array}{l}18-60 \text { years } \\
\text { ( } 31.62 \text { years) }\end{array}$ & $\begin{array}{l}25-62 \text { years } \\
(32.34) \text { years }\end{array}$ & \\
\hline \multirow{2}{*}{ Gender } & $74(90.2)$ & $11(91.6)$ & \multirow{2}{*}{ b0.678 } \\
\hline & $8(9.8)$ & $1(8.4)$ & \\
\hline Chills and shivering & $66(80.4)$ & $8(66.7)$ & b0.229 \\
\hline Headache & $50(60.9)$ & $10(83.3)$ & b0.116 \\
\hline Sweating & $39(47.5)$ & $8(66.6)$ & b 0.216 \\
\hline Fatigue & $33(40.2)$ & $6(50)$ & b0.368 \\
\hline Nausea & $22(23.4)$ & $3(25)$ & b0.601 \\
\hline Abdominal pain & $17(20.7)$ & $8(66.6)$ & b0.002** \\
\hline Diarrhea & $5(6.1)$ & $6(50)$ & ${ }^{b}<0.001 * *$ \\
\hline Splenomegaly & $52(63.4)$ & $11(91.7)$ & b0.046** \\
\hline Hepatomegaly & $23(28)$ & $6(50)$ & b0.116 \\
\hline $\begin{array}{l}\text { Leukocyte } \\
\left(<500010^{3} / \mu \mathrm{L}\right)\end{array}$ & $52(63.4)$ & $6(50)$ & bo. 0.279 \\
\hline $\begin{array}{l}\text { Thrombocytopenia } \\
\left(10^{3} / \mu \mathrm{L}\right)\end{array}$ & $73(89.1)$ & $12(100)$ & b0.276 \\
\hline $50,000-150,000$ (mild) & $44(53.7)$ & $4(33.3)$ & b0.188 \\
\hline$<50,000$ (severe) & $29(35.4)$ & $8(66.6)$ & ${ }^{\mathrm{b}} 0.041^{\star \star}$ \\
\hline $\begin{array}{l}\text { Hemoglobin } \\
\text { (<13 g/dL) }\end{array}$ & $64(78)$ & $12(100)$ & b0.065 \\
\hline $\begin{array}{l}\text { LFT (AST, ALT) } \\
(>40 \mathrm{IU} / \mathrm{L})\end{array}$ & $44(53.6)$ & $4(33.3)$ & b0.188 \\
\hline
\end{tabular}

** $p<0.05$, aStudent's t-test, bPearson chi-square test, LFT: Liver function test, AST: Aspartate aminotransferase ALT: Alanine aminotransferase, SD: Standard deviation

from Syria to Turkey. All cases followed up for malaria by our institute in the recent 10 years were imported cases. A study reported that no indigenous malaria case was detected since 2010 in Turkey and that $P$. vivax malaria cases identified in the recent 10 years were hypnozoite relapse of previous malaria (9). Hence, only imported cases were determined in recent years (9-13). The eradication of malaria cases through the years in Turkey indicates the success of malaria control practices. The increased number of imported cases can be explained by increased travel opportunities to highrisk regions with higher business opportunities. However, the risk of re-emergence of indigenous malaria continues owing to the presence of female Anopheles mosquitoes, the infectious agent for malaria, in our country, irregular migration, subtropical region location of Turkey where malaria can be transmitted through, and increased mean air temperature observed because of climate change.

Malaria may be seen in both genders; however, most of the patients were male. This can be explained by the higher frequency of travel and labor force mobility by men. Although malaria may occur in every age, malaria was reported in patients aged $20-40$ years (10-13). The mean age of patients hospitalized in our clinic was $32.4 \pm 4.56$ years. This may explain the finding that malaria more commonly occurred in young adults because this group travels more frequently for business and tourism. In our analysis of the anamnesis of our patients regarding their previous trips, patients diagnosed with $P$. falciparum and $P$. vivax malaria had traveled to Africa and the Far East (Afghanistan, Pakistan, India), respectively. This data distribution is consistent with epidemiological data of malaria reported by WHO (4).

In this study, severe malaria was found in 12 (12.76\%) patients. Studies from different countries have similarly reported a severe malaria rate of 15\%-17.3\% $(14,15)$. Fever was the most frequently seen finding in these studies. The lack of a typical malaria course accompanied with shivering in $33.3 \%$ of the patients with severe malaria may be attributed to weak immunity, so malaria may become severe in these patients. Physical examination may reveal hepatomegaly, splenomegaly, abdominal tenderness, and altered intestinal habits.

During the disease couse, anemia develops because of the abnormal degradation of erythrocytes, increased amounts of pigments released from the degraded erythrocytes lead to jaundice, and deposition of these pigments in the reticuloendothelial system results in hepatosplenomegaly (16). Splenomegaly is caused by increased erythrocyte degradation and indicates the stage of the disease. In this study, splenomegaly was found in 11 (91.6\%) and 52 (63.4\%) patients with severe malaria and mild malaria, respectively. Since splenomegaly is accepted as a parameter that indicates the disease stage, a delay in diagnosis and initial presentation to the hospital may be considered in severe malaria.

A broad spectrum of changes in complete blood count may be present. In this study, thrombocytopenia $\left(<50,00010^{3} /\right.$ $\mu \mathrm{L}$ ) was detected in $66.6 \%$ of patients with severe malaria and was considered associated with disease severity $(p=0.041)$. Similarly, Hanson et al. (17) and Rao et al. (18) have demonstrated that severe thrombocytopenia is an indicator of disease severity in adults.

Studies on adult patients have demonstrated varying frequencies in diarrhea (1.1\%-43.8\%), and diarrhea was 
found in $11.7 \%, 50 \%$, and $6.1 \%$ in all patients, patients with severe malaria, and patients with other cases of malaria, respectively $(11,19-24)$. Although the incidence of diarrhea in the present study was higher in patients with severe cases than in patients with other cases $(p<0.001)$, the frequency of diarrhea was not associated with severe cases in the study by Arnold et al. (19). Furthermore, they have reported a lower rate of diarrhea. Such differences may be considered; findings of abdominal distension such as abdominal pain and diarrhea indicate gastrointestinal tract insufficiency, which is a symptom of multiorgan failure in the pathogenesis of severe malaria and is associated with the differences in the abundance of gut microbiota. Different studies have reported that P. falciparum infection was associated with increased intestinal permeability and that parasites may be identified even in the intestinal mucosa of patients who had severe malaria (25-27). In our study, abdominal pain was also linked with disease severity, just as diarrhea, and it may be due to splenomegaly, which is similarly associated with disease severity, aside from diarrhea.

The management of patients with severe malaria presents a broad spectrum of clinical challenges because of the complicated pathophysiology and involvement of multiple organ systems. The most important aspect of treatment is rapid administration of effective antimalarial treatment and provision of concurrent supportive care to manage lifethreatening complications. Supportive precautions (e.g., oxygen, ventilator support, and cardiac monitoring) should be taken properly. Intravenous catheters should be placed, and blood samples should be immediately obtained for necessary laboratory tests. Central nervous system pathologies such as intracranial hemorrhage and bacterial meningitis should be ruled out in unconscious patients. The differential diagnostic tests and antimalarial treatment should be performed concurrently with supportive treatments including anticonvulsants, intravenous administration of glucose and fluids, antipyretics, and antibiotics, and blood transfusion. The adequacy of antimalarial chemoprophylaxis depends on antibiotic resistance and compliance with the recommended duration and dosage. Individuals who will travel to other countries should be given recommendations on the contagious disease state of the related country, required vaccinations, drugs for antimalarial prophylaxis, and pretreatment protective precautions by relevant authorities (28).

\section{CONCLUSION}

Delays in the diagnosis and treatment of malaria increase morbidity and mortality. In this study, the incidence of abdominal pain, diarrhea, splenomegaly, and deep thrombocytopenia was significantly higher in severe malaria cases than in other cases, and these factors can be accepted as predictors of severe malaria. Therefore, all patients diagnosed with malaria had imported P. falciparum malaria cases, and patients with altered consciousness state, abdominal pain, diarrhea, and renal dysfunction need closer monitoring and observation, considering the risk of these patients to complications and a severe clinical course. Patients with splenomegaly and deep thrombocytopenia need close monitoring considering their risks of complications such as spontaneous splenic rupture and hemorrhage as well as a severe clinical course. The risk for bacteremia secondary to increased intestinal changes should be also considered, including the fact that hypotension may develop because of dehydration in patients with abdominal pain and diarrhea. Pre-travel information and chemoprophylaxis may be life saving for individuals who will travel to endemic regions. Patients who presented to the hospital with a feverish picture should be assessed about their history of foreign travel, and malaria should be included in the differential diagnosis of every feverish disease to obtain an opportunity for early diagnosis and treatment.

\section{ETHICS}

Ethics Committee Approval: The study was approved by the University of Health Sciences Turkey, Bakırköy Dr. Sadi Konuk Training and Research Hospital Local Ethics Committee (2019-04-15/2019-78).

Informed Consent: Informed consent forms were signed by the patients.

\section{Authorship Contributions}

Concept: R.K., Ş.N.K., N.D.S., K.K.Y., Design: R.K., S..N.K., N.D.S., K.K.Y., Data Collection or Processing: R.K., N.D.S., S.Ş., E.C.Ü., Analysis or Interpretation: R.K., N.D.S., S.Ş., H.K., K.K.Y., Literature Search: R.K., E.C.Ü., S.Ş., K.K.Y., Writing: R.K., Ş.N.K., N.D.S., S.Ş., K.K.Y.

Conflict of Interest: No conflict of interest was declared by the authors.

Financial Disclosure: The authors declared that this study received no financial support.

\section{REFERENCES}

1. Mace KE, Arguin PM, Lucchi NW, Tan KR. Malaria Surveillance United States, 2016. MMWR Surveill Summ 2019;68:1-35.

2. Gruell H, Hamacher L, Jennissen V, Tuchscherer A, Ostendorf N, Löffler T, et al. On Taking a Different Route: An Unlikely Case of Malaria by Nosocomial Transmission. Clin Infect Dis 2017;65:14046.

3. Owusu-Ofori AK, Betson M, Parry CM, Stothard JR, Bates I. Transfusion-transmitted malaria in Ghana. Clin Infect Dis 2013;56:1735-41. 
4. World malaria report 2020: 20 years of global progress and challenges. Geneva:

World Health Organization; 2020. Licence: CC BY-NC-SA 3.0 IGO. (Accessed May 30,2021)

5. Baird JK. Severe and fatal vivax malaria challenges 'benign tertian malaria' dogma. Ann Trop Paediatr 2009;29:251-2.

6. Cox-Singh J, Hiu J, Lucas SB, Divis PC, Zulkarnaen M, Chandran P, et al. Severe malaria - a case of fatal Plasmodium knowlesi infection with post-mortem findings: a case report. Malar J 2010;9:10.

7. White NJ, Pukrittayakamee S, Hien TT, Faiz MA, Mokuolu OA, Dondorp AM. Malaria. Lancet 2014;383:723-35.

8. World Health Organization. Guidelines for the treatment of malaria, 3rd ed, WHO, Geneva 2015. http://www.who.int/malaria/ publications/atoz/9789241549127/en/ (Accessed May 30,2021)

9. Turkish Ministry of Health Health Statistics Yearbook. Available at https://www.saglik.gov.tr/TR,11588/istatistik-yilliklari.html. (Accessed May 25, 2021).

10. Şahin Si, Çabalak M, Bal T, Ocak S, Önlen Y, Çulha G. Retrospective Analysis of Cases with Imported Malaria in Hatay Province of Turkey: Seventy-Five Cases in Ten Years. Turkiye Parazitol Derg 2019;43:60-4.

11. Sarı ND, Yörük G. Retrospective Evaluation of 31 Malaria Cases Hospitalized in Our Clinic Between 2012-2018. Turkiye Parazitol Derg 2019;43:170-4.

12. Bozkurt I, Karslıoğlu M, Esen Ş. Clinical annd laboratory Features of travel-associated malaria;a University Hospital experience. Mediterr J Infect Microb Antimicrob 2018;7:7-26.

13. Sağmak Tartar A, Akbulut A. Epidemiological, Clinical, and Laboratory Evaluation of Plasmodium falciparum Malaria Cases Followed in Firat University Hospital: A 6-Year Retrospective Analysis. Turkiye Parazitol Derg 2018;42:1-5.

14. Jauréguiberry S. Accès palustre grave [Severe and complicated malaria]. Rev Prat 2019;69:162-5.

15. Boushab BM, Ould Ahmedou Salem MS, Ould Mohamed Salem Boukhary A, Parola P, Basco L. Clinical Features and Mortality Associated with Severe Malaria in Adults in Southern Mauritania. Trop Med Infect Dis 2020;6:1.

16. Fairhurst RM. Wellems TE. Plasmodium Species (Malaria). In: Mandell GL, Bennet JE, Dolin R (eds). Principles and Practice of
Infectious Diseases. 7th ed. Philadelphia: Churchill Livingstone; 2015. p. 3437-62.

17. Hanson J, Phu NH, Hasan MU, Charunwatthana P, Plewes K, Maude RJ, et al. The clinical implications of thrombocytopenia in adults with severe falciparum malaria: a retrospective analysis. BMC Med 2015;13:97.

18. Rao BS, Vano MS, Latha GJ, Lavanya D. Incidence, Severity, Prognostic Significance of Thrombocytopenia in Malaria. Int J Res Med Sci 2015;3:116-21.

19. Arnold BJ, Tangpukdee N, Krudsood S, Wilairatana P. Risk factors of shock in severe falciparum malaria. Southeast Asian J Trop Med Public Health 2013;44:541-50.

20. He D, Zhang Y, Liu X, Guo S, Zhao D, Zhu Y, et al. Epidemiological and clinical features of Plasmodium falciparum malaria in united nations personnel in Western Bahr el Ghazal State, South Sudan. PLoS One 2013;8:e55220.

21. Doltario AB, Menon LJB, Bollela VR, Martinez R, de Almeida E Araújo DC, da Fonseca BAL, et al. Malaria and other febrile diseases among travellers: the experience of a reference centre located outside the Brazilian Amazon Region. Malar J 2016;15:294.

22. Kean BH, Reilly PC Jr. Malaria - the mime. Recent lessons from a group of civilian travellers. Am J Med 1976;61:159-64.

23. Robinson P, Jenney AW, Tachado M, Yung A, Manitta J, Taylor K, et al. Imported malaria treated in Melbourne, Australia: epidemiology and clinical features in 246 patients. J Travel Med 2001;8:76-81.

24. Zaher T, Ahmadi M, Ibrahim A, El-Bahnasawy M, Gouda H, Shahat SA. Malaria in Egypt, Saudi Arabia and Yemen: a clinical pilot study. J Egypt Soc Parasitol 2007;37:969-76.

25. Wilairatana P, Meddings JB, Ho M, Vannaphan S, Looareesuwan S. Increased gastrointestinal permeability in patients with Plasmodium falciparum malaria. Clin Infect Dis 1997;24:430-5.

26. Seydel KB, Milner DA Jr, Kamiza SB, Molyneux ME, Taylor TE. The distribution and intensity of parasite sequestration in comatose Malawian children. J Infect Dis 2006;194:208-5.

27. Pongponratn E, Riganti M, Punpoowong B, Aikawa M. Microvascular sequestration of parasitized erythrocytes in human falciparum malaria: a pathological study. Am J Trop Med Hyg 1991;44:168-75.

28. Turkey's General Directorate of Health for Borders and Coasts. Available at http://www.hssgm.gov.tr/EN/ (Accessed May 4, 2021). 